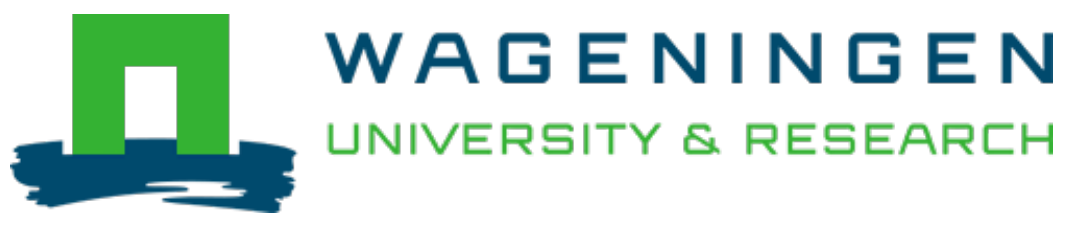

\title{
A History of Pigs in China: From Curious Omnivores to Industrial Pork
}

The Journal of Asian Studies

Lander, Brian; Schneider, Mindi; Brunson, Katherine

https://doi.org/10.1017/S0021911820000054

This article is made publicly available in the institutional repository of Wageningen University and Research, under the terms of article $25 \mathrm{fa}$ of the Dutch Copyright Act, also known as the Amendment Taverne. This has been done with explicit consent by the author.

Article 25 fa states that the author of a short scientific work funded either wholly or partially by Dutch public funds is entitled to make that work publicly available for no consideration following a reasonable period of time after the work was first published, provided that clear reference is made to the source of the first publication of the work.

This publication is distributed under The Association of Universities in the Netherlands (VSNU) 'Article $25 \mathrm{fa}$ implementation' project. In this project research outputs of researchers employed by Dutch Universities that comply with the legal requirements of Article $25 \mathrm{fa}$ of the Dutch Copyright Act are distributed online and free of cost or other barriers in institutional repositories. Research outputs are distributed six months after their first online publication in the original published version and with proper attribution to the source of the original publication.

You are permitted to download and use the publication for personal purposes. All rights remain with the author(s) and / or copyright owner(s) of this work. Any use of the publication or parts of it other than authorised under article $25 \mathrm{fa}$ of the Dutch Copyright act is prohibited. Wageningen University \& Research and the author(s) of this publication shall not be held responsible or liable for any damages resulting from your (re)use of this publication.

For questions regarding the public availability of this article please contact openscience.library@,wur.nl 


\section{A History of Pigs in China: From Curious Omnivores to Industrial Pork}

\section{BRIAN LANDER $₫$, MINDI SCHNEIDER $®$, AND KATHERINE BRUNSON}

Pigs have played a central role in the subsistence and culture of China for millennia. The close relationship between pigs and people began when humans gradually domesticated wild pigs over 8,000 years ago. While pigs initially foraged around settlements, population growth led people to pen their pigs, which made them household trash processors and fertilizer producers. Household pigs were in daily contact with people, who bred them to fatten quickly and produce larger litters. Early modern Europeans found Chinese pigs far superior to their own and bred the two to create the breeds now employed in industrial pork production around the world, including China. In recent decades, industrial farms that scientifically control every aspect of pigs' lives have spread rapidly. Until recently, most Chinese people ate pork only on special occasions; their ability in recent decades to eat it regularly exemplifies China's increasing prosperity. Meanwhile, vast areas of North and South American farmland are now devoted to growing soybeans to feed hundreds of millions of pigs in China, and the methane, manure, and antibiotic resistance they produce creates environmental and health problems on a global scale.

Keywords: pigs, China, animals, agriculture, livestock, food, environment

A farmer who doesn't raise pigs is like a scholar who doesn't read books.

種田不飬猪, 秀才不讀書

—An old Chinese saying (Zhang and Chen 1983, 62)

\section{INTRODUCTION}

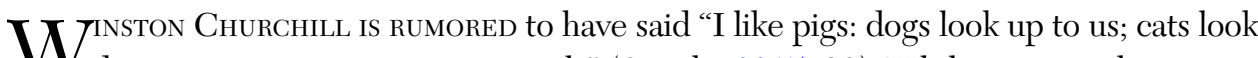
down on us; pigs treat us as equals" (Speake 2015, 82). While pigs may have seen a kindred spirit in Churchill, his statement reflects an opinion widely held by those who have looked a pig in the eye: they look back at us with confidence and intelligence. And we do have a lot in common. We are both gregarious omnivores whose dietary flexibility engendered a curious disposition as well as simpler digestive physiology

Brian Lander (brian_lander@brown.edu) is Assistant Professor of History \& Environment and Society at Brown University. Mindi Schneider (mindi.schneider@wur.nl) is Assistant Professor of Sociology of Development and Change at Wageningen University, the Netherlands. Katherine Brunson (kbrunson@wesleyan.edu) is Assistant Professor of Archaeology at Wesleyan University. 
and metabolisms than more specialized feeders. We are around the same size and have similar skin, inner organs, and cardiovascular systems (Swindle and Smith 2015). By being intelligent omnivores, we have both flourished across many different environments. The partnership between humans and domesticated animals has been so successful that we have replaced most of the other mammals on earth: humans and our livestock now make up over 95 percent of mammalian biomass on earth, half of which is composed of humans and pigs. ${ }^{1}$ The relationship between people and pigs began as a partnership, but humans now raise pigs in a relationship that can only be described as exploitation.

Chinese pigs have played a leading role in the global history of pigs. In 2018 China was home to half of the world's 1.3 billion pigs (USDA 2018). Not only did pigs occupy an important place in the history of Chinese agriculture and cuisine, but most pigs eaten in the world today descend in part from pigs that were domesticated in China. Chinese farmers bred pigs that matured and reproduced quickly, and early modern Europeans bred these with their own pigs to produce "improved" breeds that became the basis for the modern industrial pig. This article traces the history of pigs in China from wild pigs through their long history as village pigs to their current status as capitalist pigs (White 2011). Along the way, it will show how pig history and human history have become inseparable.

The Western scholarly tradition long emphasized human dominion over fish, fowl, and beasts, but recent scholarship has shown that humans often had far less agency in this process than we like to think. Humans have always lived in communities composed of many species, from microorganisms to elephants, and even when we have managed to gain control over other species, it has often required considerable changes to our own societies (Crosby 1972; Mikhail 2014; Ritvo 1987; Trautmann 2015; Zeder 2012b). Rather than engage in theoretical debates, this article uses the example of pigs in China to show how the relationship between pigs and people in China has always been co-constitutive, despite changing fundamentally over the millennia (Bulliet 2005; Haraway 2008; Morton 2017). The building of this relationship entailed a transformation in almost every aspect of human existence, from emotional, religious, and symbolic life to the spatial layout of houses and landscapes.

This article is the first overview of the history of Chinese pigs in any language. In contrast to most animal histories, which focus on recent centuries, it is a collaboration between a zooarchaeologist, a historian, and a development sociologist that traces the long history of pigs and people from a time when the two species lived separately through the long process of domestication to the industrial present. While humans have experimented with hundreds of different species of plants and animals over the millennia, in recent centuries, we have come to rely on a very small number of them. To understand this, we must consider what kinds of species they were before they were domesticated and the process by which they became essential to human societies.

\footnotetext{
${ }^{\mathrm{I}}$ The total dry biomass of all living humans is estimated at 0.06 gigatons (60 million metric tons) of carbon (Gt C) and that of livestock at $0.1 \mathrm{Gt} \mathrm{C}$, one-fifth of which is composed of pigs. The total biomass of all wild mammals has been reduced to a mere 0.007 Gt $\mathrm{C}$ (Bar-On, Phillips, and Milo 2018; Smil 2013).
} 


\section{The Domestication of Pigs}

Pigs are gregarious, even-toed, hoofed mammals whose short stature makes them well suited for moving through dense vegetation (Watson 2004). Wild pigs live in groups of varying sizes and use their large ears not only to listen for danger but also to hear one another's grunts and squeals. This may be why a group of pigs is called a sounder. Their large heads end in their most famous feature, their highly sensitive and flexible noses, which they use to root in the ground for food. They have the simple stomachs of animals that eat a wide variety of plants and animals, rather than the complex guts of ruminants like cattle that specialize in digesting coarse, low-nutrient plant matter.

There are about sixteen species of wild pigs in the world, including peccaries of the Americas, warthogs and river pigs of Africa, and various species of the Sus genus, which originated, and still has its highest diversity, in Southeast Asia (Frantz et al. 2016). The ancestor of the domestic pig is Sus scrofa, the wild boar, whose native range extends across Eurasia from North Africa to Indonesia but is now found in feral form in many other places. Their ability to thrive in such diverse habitats and their success in making themselves essential to humans, even as farms replaced their forest habitat, shows how tough and adaptable pigs are.

Like most pigs, wild boars live in groups. Sows reach sexual maturity at about eight to ten months and begin mating at around eighteen months. Gestation usually lasts just under four months, after which sows give birth to litters of four to eight piglets, usually once a year (Baser, Ford, and Kensinger 2001). Mothers and their litters often band together in groups (Nowak 1999). While females stay with their mothers until they begin mating, males leave voluntarily or are expelled from the sounder, often coming together in groups of young boars who wait their turn to challenge older males for the chance to mate. Wild pigs are not territorial but tend to have fixed spots in their range, such as those for sleeping (which can occupy half of their time) and for defecating, which is generally done at a single spot separate from their sleeping and eating areas. Pigs are not the filthy creatures they are popularly imagined to be, though they have little choice if confined in pens (Mizelle 2011).

Genetic and zooarchaeological evidence indicates that pigs were domesticated from wild boars in multiple locations across Eurasia (Price and Hongo, forthcoming). This process began with people managing wild boar populations. In western Eurasia, we know that people valued boar because they transported them by boat from the mainland to Cyprus (Vigne et al. 2011). Such a close relationship with a nondomesticated animal is not surprising, as it is becoming increasingly clear that people around the world often tamed and lived alongside various kinds of animals. Zooarchaeological evidence of gradual changes in skeletal morphology and culling practices in Anatolia suggest that the period of managing wild herds was followed by several millennia of gradual domestication (Ervynck et al. 2001; Hongo and Meadow 1998; Redding and Rosenberg 1998). Domesticated pigs were then introduced to Europe, where they continued to interbreed with wild populations (Larson et al. 2007; Ottoni et al. 2013).

In China, pigs were domesticated at least once and perhaps multiple times. Zooarchaeological evidence suggests that they may have been domesticated independently in the Yellow, Yangzi, and Liao River valleys (Luo 2012). The earliest archaeological evidence for pig domestication in the Yellow River valley comes from the site of Jiahu in Henan 
(ca. 9,000-7,800 years ago), where changes in the size and shape of teeth, an increased proportion of pig bones compared with those of other animals, and the fact that pigs were killed at a younger age all point to management of pigs by humans (Cucchi et al. 2011; Luo and Zhang 2008). Several other sites in the Yellow River valley have similar evidence, though scholars disagree on whether this dates to 7,800-7,300 years ago or later than 6,000 years ago (Barton et al. 2009; Qi, Lin, and An 2006; Yuan and Flad 2002). There is also archaeological evidence that pigs were independently domesticated in the Yangzi River valley (Yuan and Yang 2004; Yuan and Flad 2002). And there may have been a third center of domestication in the Western Liao River valley of Manchuria, where pigs were used in ritual practices. Pig skulls were frequently found in pits and buried under houses (Yuan 2006; Zhongguo 1997), and entire pig skeletons were found in a high-status burial at the site of Xinglongwa (ca. 8,200-7,400 years ago).

While zooarchaeological evidence suggests three independent domestication events, DNA evidence is less clear. Mitochondrial DNA analyses of living domestic pigs in East Asia show that they cluster into several lineages - two of which are centered in the Yellow River valley and Yangzi River valley regions - which also suggests that these two regions were centers of domestication (Larson et al. 2005, 2010). However, ancient DNA research reveals that the earliest pigs in all three regions belong to the same mitochondrial DNA lineage. This suggests that domestic pigs were introduced from the Yellow River region or that there was parallel domestication in these regions with gene flow between various wild and domestic pig populations during the initial stages of domestication (Xiang et al. 2017). These studies also suggest long-term genetic continuity between ancient and modern Chinese domestic pigs, which means that Chinese pigs are direct descendants of indigenous wild boar populations (Larson et al. 2010; Xiang et al. 2017). The middle Yellow River region was clearly a center of domestication, but the evidence for domestication in other regions of China remains unclear.

Regardless of whether pigs were domesticated once or several times in East Asia, early pig exploitation in all three regions is linked to significant socioeconomic changes beginning about 9,000 years ago. Neolithic peoples domesticated dogs, came to rely on crops like millet and rice, began to make ceramics and ground stone tools, and settled down to live in permanent villages (Liu and Chen 2012; Wu et al. 2012; Yang et al. 2012). This was a gradual process. In both ends of Eurasia, pig domestication was characterized by several millennia of increasing management and domestication of wild boar during the slow transition in human subsistence associated with the emergence of early farming societies. Chinese pigs were eventually carried to Japan and Southeast Asia and across the Pacific as far as Hawaii (Hongo 2019; Kirch 2017).

Given that most other Eurasian domestic species were only domesticated once, it is worth asking why pigs were domesticated more than once. While scholars once assumed that pigs were domesticated when people captured and then raised them, it is increasingly clear that pigs played an active role in this process, at least in the early stages, by frequenting human settlements to scavenge on crops or human trash. During these forays, tamer pigs would have come into closer contact with humans and formed a relationship that gradually led to domestication. This is also how dogs were domesticated, and it is known as a commensal pathway to domestication (Larson and Fuller 2014; Zeder 2012a, 2012b). Since pigs are omnivores that are naturally well adapted to human ecosystems, there were many opportunities for domestication as humans modified landscapes 
during the development of agriculture across several regions of the world (Boivin et al. 2016). Pigs were not only tasty and nutritious, they also helped clear human settlements by eating rubbish, and thus they were well worth keeping around (similar to dogs in China and elsewhere: see Mikhail 2014, 67-106; Skabelund 2011, 18-19).

People in Neolithic China continued to exploit wild boar and other wild animals long after pigs were first domesticated, and the two probably continued to interbreed (Luo 2012; Yuan 1999). Genetic research shows that ancient gene flow between wild and domestic stocks was common for pigs and other domesticated animals (Gaunitz et al. 2018; Marshall et al. 2014). In parts of island Southeast Asia and Oceania, people pen female domestic pigs at night but allow them to roam freely during the day and breed with feral males, which they also hunt (Rappaport 1967; Redding and Rosenberg 1998). This is a useful model for thinking about how people in Neolithic China may have kept pigs. The presence of feral pig populations around the world today is further evidence that domestication is a fluid process (Fleischman 2017; Gibson 2016). Moreover, boar are one of the few species of larger wild animals that have remained widespread in China, even as farms have replaced forests (Clark and Sowerby 1912, 94; Smith and Xie 2008, 452).

Pigs began to play a role in the increasing hierarchy of agricultural societies in the Yellow and Yangzi River valleys about 7,000 years ago, being employed in competitive feasting and status displays (Cucchi et al. 2016; Liu and Chen 2012; Luo 2012). As in other parts of the world, sociopolitical competition promoted increasing exploitation of key domestic plants and animals. Archaeologist Bryan Hayden (1990, 2003) argues that the first plant and animal domesticates were initially used in ritual feasting events and only gradually became dietary staples; this may well be true of pigs in East Asia. The archaeological record reveals that pigs were commonly used in sacrificial and funerary rituals (Kim 1994; Liu 1996; Luo 2012; Yuan and Flad 2002, 2005), but they did not become dietary staples in the Yellow River valley until about 6,000 years ago (Cucchi et al. 2016; Ma 2005; Ma 2007). In other regions of China, pigs did not become dietary staples until several millennia after that (Yuan 1999). By the Bronze Age, pigs occupied diverse socioeconomic roles that ranged from basic subsistence to political rituals_especially sacrificial rites.

\section{Pigs during China's Historical Period, ca. 1200 BCE-1978 CE}

The main historical difference between the pigs at each end of Eurasia is that pigs in Europe continued to forage in forests and interbreed with wild boar into modern times (Grove and Rackham 2001, 190-216; Parsons 1962; Pastoureau 2009), while those in China were increasingly penned (Larson et al. 2010; Marshall et al. 2014). As population growth in the agricultural lowlands of China reduced the amount of wild land on which pigs could forage, people had to pen their pigs and take full responsibility for their feeding and breeding. Penning makes pigs fatter, and because people had to dedicate resources to feed pigs, they bred them to produce larger litters and to grow and reach sexual maturity more quickly (Pugliese et al. 2003). They also selected for tameness and lowered reactivity, with the result that the pigs' brains diminished in size by a third (Zeder 2012a). Growing populations and a consequent reduction in shared resources also led to other forms of intensification like silviculture and aquaculture, evidence that once-common resources like trees and fish had become scarce enough that people 
were forced to produce them (Shih 1982). Under these conditions, pigs were increasingly valued not only for meat but also for eating the family's rubbish and producing manure.

Across Eurasia, historians seeking historical records of pigs often find that "since pigs for the most part were taken for granted, their existence did not generate much commentary" (Malcolmson and Mastoris 1998, xiii). Chinese documents frequently mention horses, cattle, and sheep, herds of which were valuable concentrations of resources, but pigs were owned in small numbers by the plebeian masses and could not be easily taxed. For this reason, neither the literate elite nor the state was interested in them, and they are rarely mentioned in China's many texts on agriculture, husbandry, and animal medicine. Horses-essential both for armies and for those eager to display their higher status-received vastly more attention in the literature, despite being far less common. A bibliography of premodern agricultural treatises lists over seventy titles on horses and cattle but only two on pigs (Wang 2006; see also Bray 2018). Nonetheless, there is enough evidence to reconstruct the general history of pigs in the historical period.

Oracle bone inscriptions of the late second millennium BCE, the earliest Chinese writing, contain abundant records of wild and domestic pigs (豕) being hunted and sacrificed, and they contain terms for adult female (豕 + 七), adult male (刑 or 猳), castrated (豕), young (豚), and wild (氮) pigs (Wang and Yang 1999, 544; see also Schwartz 2019, 2020). Because the standard Chinese term for "house" ( $j i a$ 家) depicts a pig in a building, it is often cited as evidence of the importance of pigs to Chinese families. In fact, the "pig" element of the character was originally phonetic: scribes drew a pig inside a building not for its meaning but because the word for pig was pronounced like the word for house, thus indicating how to read the character (Huang 2007, 1359). It is now the standard word for family and the second part of “nation-family" (guojia 國家), the Chinese word for country and state.

By 2,000 years ago, there were tens of millions of people in the lowlands of North China, which had been converted almost entirely to farmland, leaving little extra land for foraging pigs (Bielenstein 1987, 193). Over the subsequent millennium, the Lower Yangzi region also became densely populated. A thirteenth-century CE agricultural treatise states that lakes and mountains were the best places in that region to raise pigs, presumably because they were the only places that still had wild plants for pigs to eat (Kuo 2013, 75). Similarly, an eighteenth-century manual states that while pigs near mountain forests could be fed acorns, chestnuts, leaves, and herbs and those near lakes could be fed aquatic plants, farmers in other areas had to collect tree leaves for pigs and also feed them their own crops, like melons, leafy plants, and Chinese yams (Zhang 1989, 585; see also Yang [1740] 1962, 165). In general, people only fed grain to piglets and high-value pigs like those raised to produce fancy ham (Kuo 2013, 182; Wittwer 1987; Yang [1740] 1962, 164).

The growing density of human populations helps explain why pigs became so common. While the increasing agricultural population eliminated larger wild mammals from the lowlands of China, it also reduced the availability of grazing land for sheep, cattle, and horses (Lander and Brunson 2018). The result was that the role of these animals in Chinese agriculture was much smaller than in that of most other parts of Eurasia, though sheep and goats were still common in hilly or arid regions with marginal farmland (Bray 1984). The only domesticated animals able to thrive in most villages were pigs, dogs, and chickens, all omnivores able to eat whatever was available (see figure 1). 

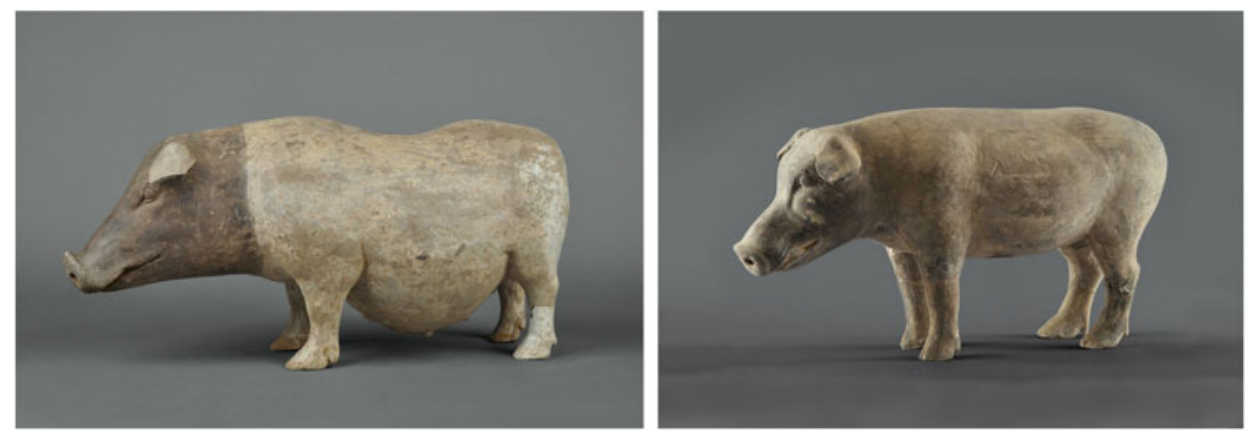

Figure 1. Ceramic models of domestic pigs excavated from the Yang Mausoleum in Xianyang, Shaanxi, the tomb of Han Emperor Jing (d. 141 BCE) (http://www.metmuseum.org/art/collection/search/640948). Thanks to the Shaanxi Institute of Archaeology for permission to use these images.

Most households raised only a few pigs each year, which they slaughtered for important celebrations like weddings and the Spring Festival (Chinese New Year). While these were the only times many people ate fresh pork, they also preserved meat and saved lard to cook with after the festivities ended (Huang 2000). Lard was commonly used to fry vegetables and valued for the flavor it imparted. Because pig diets were composed primarily of carbohydrates (in the form of coarse plants and kitchen scraps) with very little protein, the meat of most Chinese breeds was fattier than today's pork. Cooking methods and dishes were based on this characteristic and the forms and flavors it produced. Fat contains more than twice as much energy as carbohydrates or proteins, and it was often a delicacy in agrarian societies, in which people were more likely to be hungry than obese (Smil 2008, 121). Many Chinese pork dishes, most famously Mao Zedong's favorite "red braised pork belly," consist mostly of tender lard.

Given how rarely common people ate pigs, they might not have considered them worth the effort of raising if they had not also provided other services, namely, cleaning up waste and producing fertilizer. The ability of pigs to clean up farm villages by eating almost every kind of waste was probably valued from early times. Stable isotopes extracted from pig bones found at Neolithic sites in North China indicate that pigs ate plenty of human food waste and other rubbish (Barton et al. 2009; Cucchi et al. 2016; Ma et al. 2016; Pechenkina et al. 2005). ${ }^{2}$ As populations grew, pig manure became increasingly important. Population growth reduced the amount of arable land per person, forcing people to reduce fallows and plant crops more often on the same land, which was only possible with fertilizer. For poorer farmers who rarely had the luxury of eating their pigs, manure production was often the main purpose of raising pigs. This article's epigraph, which states that farming without raising pigs is like being a scholar without reading books, means that pig manure is as important to farmers as books are to scholars.

${ }^{2}$ Elevated levels of $\delta^{13} \mathrm{C}$ (a stable isotope of carbon) in excavated pig bones suggest that pigs ate plenty of millet, a $\mathrm{C} 4$ plant. Elevated levels of $\delta^{15} \mathrm{~N}$ (a stable isotope of nitrogen) reflect diets that included significant amounts of meat, feces, or food grown in manure. 


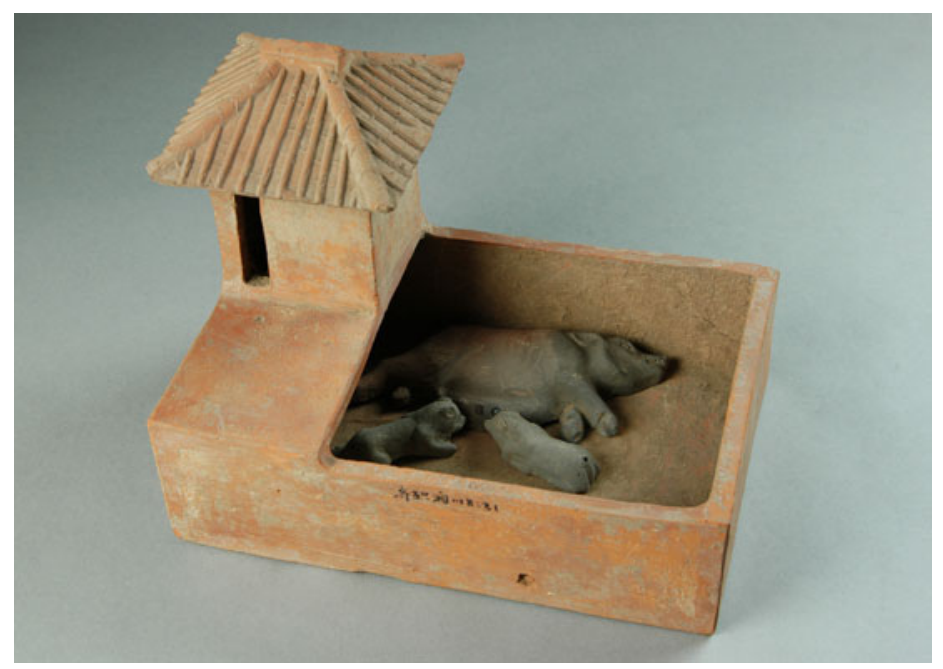

Figure 2. Ceramic model of a privy over the pen of a nursing sow with piglets excavated from a Western Han (final two centuries BCE) tomb in Jiyuan, Henan (Henan sheng bowuguan 1973). (CHenan Museum.

People in early China often built privies over pigsties, an ingenious way to provide pigs a safe living space that was also a waste disposal system and convenient source of manure (Nemeth 1998; Xiao 1986) (see figure 2). We know of these privies from many ceramic figurines buried in tombs from the Han dynasty (ca. 200 BCE-200 $\mathrm{CE}$ ), presumably to ensure that the dead had access to a toilet, manure, and pork. Given their proximity to houses, the pens were probably cleaned regularly to reduce the smell, so we should not assume that privy pigs lived in piles of filth. Agricultural treatises emphasize the importance of keeping them clean for the health of the pigs. People were acutely aware of the danger of diseases to pigs, which are mentioned in several works (Kuo 2013, 87-110). The fact that people, pigs, and other animals lived in proximity for millennia allowed them to share many diseases, although how and when this happened remains unclear (Morand, McIntyre, and Baylis 2014; Pearce-Duvet 2006).

While people kept them for sanitation, manure, and food, pigs were much more than just possessions; they were also intelligent beings with whom farming families interacted every day and thus had meaningful relationships (Malcolmson and Mastoris 1998). As with subsistence farmers and herders around the world, people paid careful attention to the well-being of their pigs, not only because they were valuable but because they were members of families and communities. The fact that these were genuine relationships is not diminished by the fact that people ended up eating or selling the pigs.

The sixth-century agricultural manual Essential Techniques for the People (Qimin yaoshu 齊民要術), which was written in the North China Plain, contains a brief section on raising pigs (Jia, Miao, and Miao 2006). It recommends that females with short snouts and no soft hair should be chosen for breeding, based on the logic that short-snouted pigs fatten more quickly and soft fur is difficult to extract when making leather. It advises farmers to raise female piglets separately from their mothers in order to fatten them more quickly but to leave male piglets with their mother to create a family bond that would discourage males from running away when they are 
let out to forage. It suggests letting pigs out to forage in the warmer seasons and stockpiling various agricultural residues like chaff and brewing dregs to feed them during the winter months. It also contains instructions on castration and incubating newborn piglets in a steamer, and it suggests half-burying cart wheels to make pens that would allow piglets, but not their mothers, to move freely in and out. Many of these practices were later adopted by industrial pig farmers.

While pigs had an important place in the domestic economy, they became valuable commodities wherever there were markets. China has been a mercantile society for well over 2,000 years. Butchers served an important function, selling small quantities of meat so that people who could afford to eat meat could do so without having to kill a whole pig. Hundreds of pigs were slaughtered every day in large cities, like twelfth-century Hangzhou (Gernet 1962, 46; Kuo 2013, 71). As commerce expanded after around 1500, people increasingly raised pigs for the market. A division of labor emerged in which services like castration were performed by traveling specialists (Kuo 2013, 92-107). Specialist producers of high-quality ham also emerged to supply expanding markets (Kuo 2013). It should be noted that there has been a substantial Muslim population in China's northwest for over a millennium who tended not to dine with pork eaters, so that their pork avoidance became a central element of their identity.

The result of millions of farmers breeding pigs over millennia was the creation of a wide variety of regional breeds. In 1960, China's first national survey of indigenous livestock identified more than one hundred indigenous pig breeds, with countless locally adapted varieties that could thrive in a variety of landscapes and climatic conditions (Cheng 1984). The enormous diversity makes it difficult to generalize, but southern pigs were smaller and more fecund while northern pigs tended to be larger and hairier, suited to foraging on harvested fields during cold winters, and probably still bred with wild boar (Clark and Sowerby 1912, 42, 137). Eventually these southern pigs were carried to Europe, where they were bred with local pigs to create the industrial hog breeds that now constitute most of the world's pigs.

\section{The Contribution of Chinese Pigs to Modern Breeds}

The Romans developed a breed of short, fat, pen-raised pigs that were markedly different from the semi-wild foraging types and probably had some similarities with Chinese penned pigs. But these pigs disappeared along with the Roman Empire and its pork-loving aristocracy (Essig 2015, 65-76; MacKinnon 2001). In contrast, pig breeding continued without disruption throughout Chinese history. By the seventeenth century, China's pigs matured and fattened much faster and had more offspring than European pigs, which continued to interbreed with wild boar. Because ships frequently carried live pigs to eat on the voyage, it is not surprising that Chinese pigs arrived in Europe, where farmers bred them with native breeds (see figure 3). This was a decisive event in the history of pigs. Sam White (2011) has argued that European pigs produced meat so inefficiently that they might have dropped out of the modern meat industry altogether if Europeans had not discovered Chinese pigs.

Differences in maturation rates and litter size between wild boar and Chinese pigs illustrate the degree to which the latter were selectively bred for fast and vigorous 


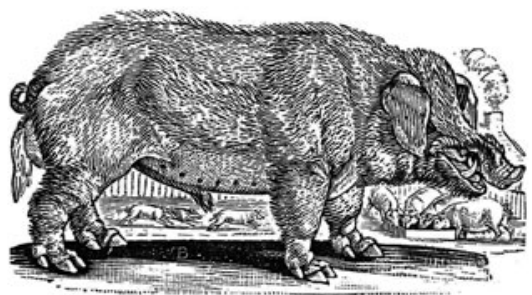

THE COMMON BOAR

(Sus Scrofa, Lin.-Le Cochon, Buff.)

Is, of all other domestic quadrupeds, the most filthy and impure. Its form is clumsy and disgusting, and its appetite gluttonous and excessive.

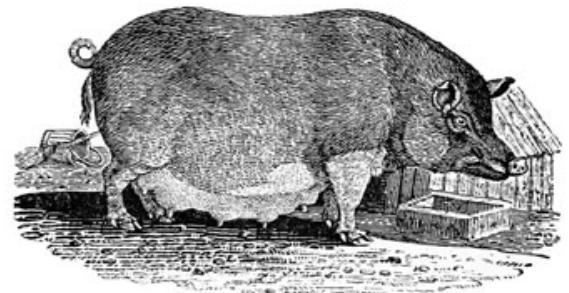

SOW OF THE IMPROVED BREED.

By a mixture of the Chinese black Swine with others of the larger British breed, a kind has been produced which possesses many qualities superior to either of the original stocks. They are very prolific, are sooner made fat than the larger kind, upon less provisions, and cut up, when killed, to more useful and convenient portions.

Figure 3. The "common boar" on the left is a depiction of the native British breed of domestic pigs, while the text on the right reveals how highly the mixed breeds were regarded (Bewick 1924; first seen in White 2011).

reproduction. Wild boar reach puberty in eight to ten months and have litters of four to eight piglets, while Chinese Meishan pigs can reach puberty in three months, have litters of around fifteen piglets, and often produce two litters per year (OSU 2019). English pig farmers began to breed their pigs with Chinese imports no later than the eighteenth century, greatly increasing meat productivity. This occurred in the context of increasingly commercialized agriculture, in which large farms produced for the market, competing not only with other pork producers but also with other meat producers generally. The goal was to improve taste and, most importantly, to raise pigs that grew faster and bigger, thereby reducing costs. While pigs in China had often been raised for sale, the incessant competition characteristic of early capitalism led English farmers to experiment with pigs more systematically and consistently than had occurred in China.

As late as 1700, English pigs spent much of their time foraging for food, regularly interbreeding with wild or feral pigs, and took a year and a half to reach maturity (White 2011). Over the following 150 years, English farmers bred their stockier domestic breeds with fatter, quick-maturing Chinese breeds to produce such breeds as Yorkshire, Berkshire, Hampshire, and Suffolk, which could grow large enough to slaughter in as little as nine months (White 2011, 108; see also Bosse et al. 2014). The interbreeding of Chinese and Western pigs has continued since then. In the 1970s and 1980s, European and American breeders imported high-fertility pigs from China to produce new breeds, and they continue to experiment with crosses between these kinds of pigs (McOrist 2009; Tang et al. 2008). While indigenous Chinese pigs continue to exhibit local genetic variation based on millennia of local breeding, most of the world's domestic pigs today are descendants of these European-Chinese breeds (Frantz et al. 2016, 77-78; Megens et al. 2008).

In the nineteenth and early twentieth centuries, China's population grew by hundreds of millions, forcing people to farm ever more marginal land and to intensify production by carefully using pig and human manure (Worster 2017). Mao Zedong 


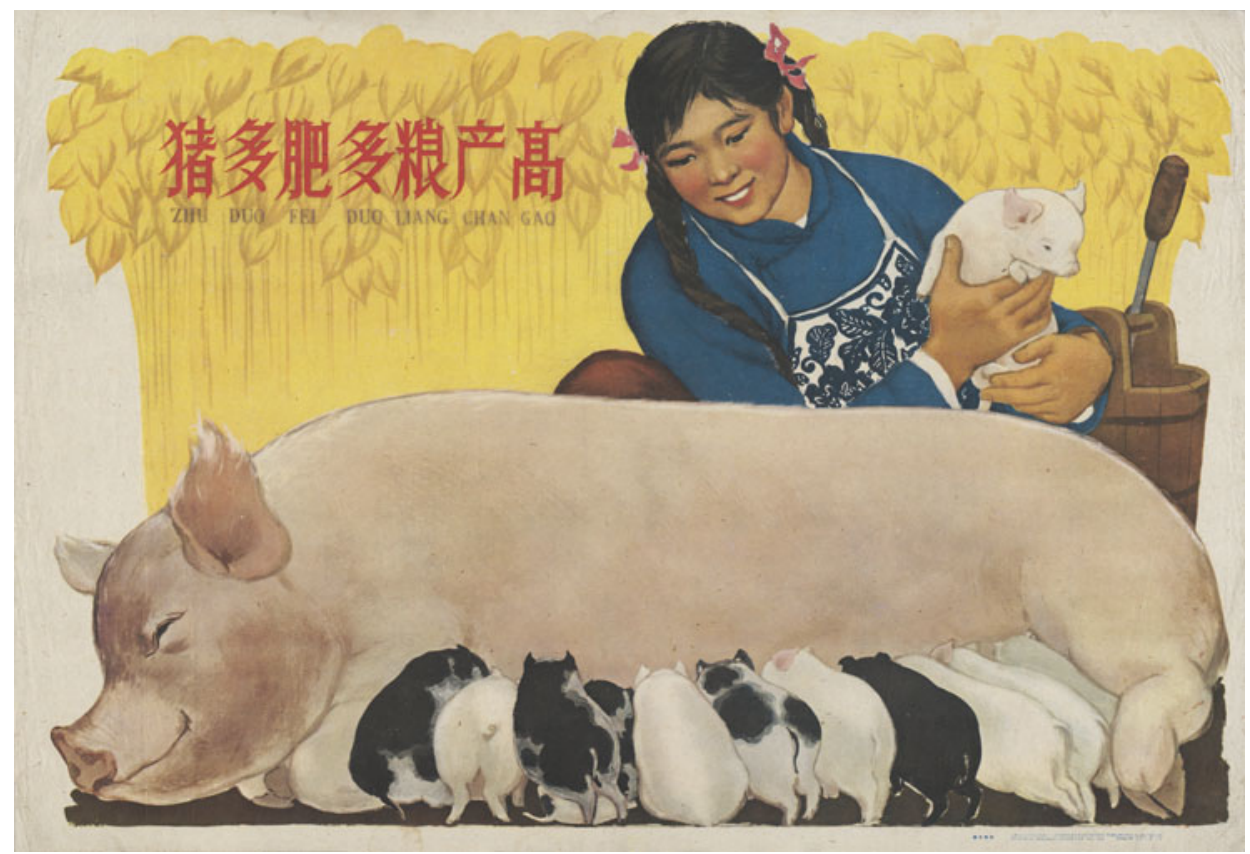

Figure 4. "More pigs means more fertilizer and higher grain production" (Yang 1959). Thanks to chineseposters.net for permission to use the image of this poster, which is held in a private collection.

praised pigs as "fertilizer factories," pointing to their importance in agricultural production and productivity and in underwriting the predominantly plant-based diets that defined China for thousands of years (Schmalzer 2002) (see figure 4). When Mao met with Richard Nixon in the early 1970s and the two countries normalized relations, the Chinese government purchased several modern nitrogen fertilizer factories. China's production of synthetic fertilizers has grown exponentially since then, greatly diminishing the agricultural importance of pig manure just as it began to be produced in ever-greater quantities (Marks 2017, 311-16). Given the scale of industrial pork production today, the substitution of manure with synthetic fertilizers has transformed manure from a valuable agricultural input to a source of crippling waste on a national scale.

\section{Industrial Pigs in Modern China}

The most dramatic change in the relationship between people and pigs in China has occurred over the past forty years, with the industrialization of pig farming and the movement of pig production from the household to the so-called factory farm. This new system is a radical departure from the "traditional" mode of pig raising in terms of scale, time, inputs, outputs, and labor. Until 1985, as much as 95 percent of all the pork in China was produced by smallholder farmers who raised fewer than five pigs per year on household plots (Jian 2010). Pigs historically lived for nearly a year and were slaughtered annually for Spring Festival feasts, after which their fat would be saved and used later for 
cooking vegetables. People also slaughtered pigs for weddings and other celebrations and to use as a gift to curry political or social favor (Anderson 1988; Hsu and Hsu 1977). Pigs themselves ate mostly agricultural and household scraps, either grazing on their own, or fed in pens by household members. Manure remained a valuable source of fertilizer in the Mao era, when pigs were raised variously in households and in collectives (Schmalzer 2016).

Soon after the Cultural Revolution ended in 1976, the government initiated its program of "Reform and Opening," launching decollectivization and selective liberalization and privatization of agricultural sectors and markets. Agribusiness became a site for investment and profit, and policies in the late 1980s and early 1990s were aimed at developing a domestic livestock industry, industrializing and scaling-up production, and increasing especially urban meat consumption (Schneider 2019). Confined animal feeding operations, or CAFOs, were included in the push to industrialization. CAFOs are the technological heart of industrial pig production broadly, developed in the United States in the postwar era, separating livestock and crop production agroecologically and geographically (e.g., Anderson 2019; Emel and Neo 2015; Finlay 2004; Foster and Magdoff 2000). In CAFOs, hundreds to hundreds of thousands of genetically identical (or nearly identical) animals are raised together in buildings for the entirely of their much shortened lives: because of the scientific production of genetics and feed regimens, a CAFO pig grows to slaughter weight in about six months. All of their feed is provided by (waged) workers, often at the end of commodity chains for feed that span continents.

As the structure of China's pork sector shifted, pork production and consumption skyrocketed, transforming domestic agriculture and meat consumption, and global meat markets and resource flows (Oliveira and Schneider 2015; Schneider 2019). Already in 1979 — one year into reform—China helped make pork the most produced and consumed meat in the world, overtaking beef and later doubling it. In the 1970s, there were around 500 million pigs on earth. By 2018, farmers and companies in China alone produced almost 55 million tonnes of pork from a domestic swine herd of 710 million head, half the world's total. China was also the world's largest pork importer in 2018, bringing in 1.5 million tonnes, or 19 percent of total global pork trade (USDA 2018). Although "traditional" ways of farming remain in some places, China's is now a modern, globalized pork industry.

Rural people are increasingly giving up pig raising and migrating to cities, where they provide China's booming economy with poorly paid laborers. As in the twentieth-century West, people are moving to cities where their only connection with farm animals occurs when they eat them (Bulliet 2005). In 2015 the pork sector was composed mostly of medium-scale household farms (up to 500 pigs per year), large-scale commercial farms (500-10,000 pigs per year), and mega-operations (more than 10,000 pigs per year) (Fok and Hui 2017). China’s pork is increasingly supplied by agribusiness and large-scale livestock operations, especially in cities, where meat (and pork) consumption is at least three times higher than in rural areas (Xiao et al. 2015).

\section{Breeding and Feeding the Modern Hog}

The transformation of pig farming illustrates how local-level changes simultaneously reshape the global system, starting with the body of the pig itself. The pigs that populate China's pork industry are modern hogs: "improved breeds" of Chinese and European 
ancestry that transnational and domestic genetics firms import from Europe and the United States. The most popular breeds in China, and in the world, are of the Duroc, Landrace, and Yorkshire types, commonly abbreviated "DLY." In contrast to the gregarious, omnivorous domestic pigs of premodern China, the modern hog is made explicitly to survive and thrive in industrial conditions. Modern hogs have one purpose: to convert the least amount of grain and oilseed-based feed into the highest amount of lean muscle in the shortest possible time. This is only possible through breeding programs that carefully tailor pigs to be muscle-producing machines, helped along by a combination of industrial feed mixes, antibiotics and the controlled environment of the CAFO.

Modern hogs are replacing indigenous Chinese pigs. The 1960 national livestock survey that identified more than one hundred indigenous pig breeds was followed in the 2000s by a survey that found only eighty-eight domestic breeds. The survey concluded that two decades of exotic breed importation had caused the extinction of eight breeds, left thirty-one endangered and that 85 percent of indigenous pig breeds had declined in numbers (Cheng 1984; Frantz et al. 2016; Yang 2013, 2015). By 2010, over 90 percent of the pork produced in China was from DLY pigs and indigenous-exotic hybrids, according to an official in the livestock division of China's Ministry of Agriculture (interview with Mindi Schneider, Ministry of Agriculture, Beijing, September 17, 2010). Indigenous breeds are increasingly raised only on specialty "boutique pig" farms or on state-funded and largely privately run conservation farms tasked with preserving genetic diversity. Ecologists and animal scientists are concerned with the decline of indigenous pig breeds as a loss of genetic diversity and an erosion of the ability of pigs to adapt to changing climatic conditions. Pork industry experts share this concern, as indigenous breeds have been the source of characteristics like prolificacy, adaptability, and flavor in modern breeding programs (McOrist and Walters 2009).

Along with changing genetics, the diets of Chinese pigs have changed dramatically. While traditional pigs ate various plant matter, modern hogs eat modern feed, which has more protein. In the late 1970s, China's leaders supported the development of a milling industry to provide compound livestock feeds using grains and oilseeds. However, with 21 percent of the world's population but only 9 percent of arable land, feeding China's pigs without starving China's people has required re-routing international trade, investment, and resource flows to import huge quantities of feed. Recognizing that China's soybean output could not keep up with the massive growth planned for the livestock industry, the government began to liberalize the soy sector in the 1990s, allowing imports to overtake both exports and domestic production.

After being a leading soybean exporter for decades, China became the world's largest soybean importer in 2003, and by 2014 it imported almost 60 percent of the total global soybean trade (70 million tonnes) for its livestock feed industry (Oliveira and Schneider 2015; Yan, Chen, and Ku 2016). Maize imports are also rising, and the state increasingly encourages Chinese agribusiness firms to seek access to land, resources and markets abroad (Schneider 2014). As a result, large areas of North and South America are now used to grow feed for China's pigs, fuelling the ongoing destruction of the grasslands of the southern cone of South America and the southern Amazon (Oliveira and Hecht 2018). The impact also extends into the oceans: in 2006 pigs ate about one-fifth of the world's fish meal (Smil 2013, 211). Soybeans have been a key sticking point in the ongoing US-China trade war from 2018, illustrating the important position of pigs and pork in matters of contemporary political economy. 
In adopting the science and practice of the global pork industry, China has also taken on its approach to excrement. Manure has gone from being a valuable fertilizer to a major pollutant. The massive expansion of China's swine herds has led to an explosion of manure that is no longer wanted because of the ubiquity of chemical fertilizers. Some of the nearly 5 billion tonnes of manure produced each year ends up in waterways, causing blue-green algae outbreaks, and making water unusable for many households, most of them rural. In 2010, the first national pollution census identified manure from industrial livestock facilities-mostly pigs but also chickens-as China's number-one source of water pollution. The government is encouraging the pork industry to consolidate on the assumption that large-scale, modern facilities are better able to control their pollution. Increased fines and "name and shame" campaigns have driven industrial pig production away from urban areas toward rural areas, which tend to have less environmental monitoring (Lord 2020). Increased enforcement of environmental regulations has forced hog producers to close or relocate if they lack the capital to pay fines and taxes.

\section{Crisis, Consolidation, and Consumption}

From the beginning of the reform era, the government has favored agribusiness firms known as "Dragonhead enterprises" to lead agricultural development and manage agricultural markets. In exchange for financial and policy support from the state, these firms - either state owned or private- have a double mandate to open agricultural markets and integrate rural producers into agricultural value chains. Dragonhead-led vertical integration now accounts for more than half of crop, livestock, and aquaculture production in China. Pork is an example of how vertical integration and agribusiness development has put Chinese firms like the WH Group and COFCO on a par with or in the position to overtake world-leading transnational companies (Schneider 2017). In addition to vertical integration, these companies are experimenting with vertical production. A site being built in Guangxi will raise 30,000 sows and 840,000 piglets annually in high-rise buildings. A thirteen-story building will be the tallest "pig hotel" in the world when it is completed in 2020 (Dooren 2018).

CAFOs are some of the most conducive places on earth for the transfer of influenzas and other viruses between animals and humans, a threat to both people and pigs (Borkenhagen 2019; Wallace 2016). As genetic diversity has narrowed to the point that most of China's pigs belong to the three DLY breeds or their hybrids, their ability to fend off disease has been drastically compromised. Industrial pig producers are dealing with this biological reality with antibiotics and increased regulation of the bodies and activities of workers. Before entering pig barns, workers are sanitized, wrapped in protective gear (protective for the pigs, not the workers), and often quarantined for days or weeks before being allowed contact with the "improved breed" pigs (Blanchette 2015). As elsewhere, the use of antibiotics by Chinese livestock producers has spawned a generation of antibiotic-resistant, disease-causing organisms that are found in the soils around largescale pig farms, in water and in human guts (Davis 2006; Ji et al. 2012; Luo et al. 2010). Farm managers include subtherapeutic antibiotic doses in feed rations, which has probably saved some pigs from some diseases but is ineffective against viruses, which are the most serious threat. This also helps develop antibiotic-resistant diseases that threaten both pigs and people (Hvistendahl 2012; Luo et al. 2010, 7220). 
The government is very sensitive to the threat of disease to pigs because it drives up meat prices and thus the general cost of living. Pork prices skyrocketed after hundreds of thousands of pigs were killed in the 2006 epidemic of the porcine reproductive and respiratory syndrome virus. The government responded by increasing support for large-scale, industrialized, and standardized pork production to stabilize the industry and protect against future price shocks (Wang and Watanabe 2008). These measures successfully boosted the national swine herd and supported larger-scale, intensified production (Woolsey and Zhang 2010). Health problems with industrial pigs became public in 2013, when 16,000 diseased pig carcasses were dumped into a river in Zhejiang and floated down to Shanghai (Davison 2013). But the ongoing epidemic of the African swine fever virus is far more severe than any previous crisis, having led to the deaths of well over 200 million pigs in China (USDA 2020). As in earlier crises, the government is promoting increases in the scale and standardization of production as a solution (FAO 2019).

Of all the issues associated with China's industrial pork sector, food safety concerns receive the most media and government attention (Song, Li, and Zhang 2014). Pork consumers in China are concerned about growth promoter residues, following several highprofile cases of the growth promoters clenbuterol and ractopamine being found in meat. Given the poor reputation of Chinese food products in the United States, it is worth pointing out that the use of these chemicals in meat production is illegal in China, but they are everyday components of pork production in the United States. This has proved a sticking point when Chinese corporations have purchased US pork producers (Schneider and Sharma 2014, 23). Middle-class urban consumers tend to prefer pork from factory farms or from abroad, which they view as better regulated than "backward" small-scale peasant farmers (Barcellos et al. 2013; Ma et al. 2017). But the opposite trend is also blossoming in "alternative food networks," including farmers' markets, community-supported agriculture and organic farming, whose customers also cite food safety as their primary motivation for participation (Shi et al. 2011).

As pigs and pig production in China have changed, so, too, has the meat. For most of China's history, people ate relatively little pork. When they did, they valued its high fat content and its lard. Industrial pork has become lean meat because of the much higher proportion of protein in commercial grain and oilseed-based feed mixes, combined with the characteristics of the industrial breeds. This lean meat is not the meat that enlivens Chinese culinary traditions. It does not meet the taste preferences of middle-aged and older Chinese people who have memories of pre-reform pork. Still, the market for pork continues to grow and consumption continues to rise. Processed and packaged pork products are the fastest-growing market segments. And while China's pork has become leaner, China's people have not. There are now more obese and overweight people in China than in any other nation in the world (Di Cesare et al. 2016). Pork is certainly not the only culprit, but it is an important component of changing eating habits that have led to the emergence of diet-related diseases and causes of death.

\section{Conclusion}

The long and complex relationship between people and pigs in China in many ways exemplifies the environmental history of humanity in the agricultural era. As humans 
domesticated more and more species, we were able to replace natural ecosystems with ones composed of species that benefited us, a process that has been carried further in China than almost anywhere else on earth. Humans and associated species have become one of the main forces affecting the earth's biosphere, and increasingly its climate. The relationship between pigs and people that was once beneficial for both now has significant downsides for both species.

Over the last nine thousand years, people in China domesticated pigs, kept them near their households as waste processors and sources of manure, and ate their meat at times of feasting or celebration. However, the relationship between pigs and humans has changed fundamentally in the last few decades as industrialized pork production has replaced household pig raising. A long-term perspective on the environmental history of pigs in China reveals how different_-and damaging — modern pig raising practices are from our earlier history of interactions with pigs.

While increased availability of meat has improved the health of people in China over the past generation, feeding soybeans to pigs is an extremely inefficient way to produce food. It may not be literally unsustainable to replace much of South America's forests and grasslands with farms to feed more pigs, but it is hard to justify when humans could subsist on a fraction of the soy they produce to feed livestock. Within China, the massive scale of meat production has serious consequences for humans. Our similar physiologies and the fact that the influenza virus and various other diseases can spread between pigs and people means that high concentrations of pigs are perfect sites for the spread of new viruses to humans. Moreover, the heavy use of antibiotics risks creating global diseases that are impervious to existing medicines. The massive quantities of manure produced by industrial pig farms not only constitute severe pollution in themselves, they also produce methane, a powerful greenhouse gas. For these and other reasons, high consumption of red meat is globally unsustainable (Springmann et al. 2018). The Chinese tradition of treating pork as a luxury food eaten only on special occasions was probably the right idea.

\section{Acknowledgments}

We would like to thank Stewart Cole, Madelaine Drohan, Enno Giele, David Lord, Max Price, and the Science, Technology, Environment and Medicine group of the Brown University History Department for their comments on this article. Katherine Brunson would like to thank the Joukowsky Institute for Archaeology and the Ancient World and the Brown University Center for Computational Molecular Biology. Mindi Schneider is grateful to the Netherlands Institute for Advanced Study in the Humanities and Social Sciences (NIAS-KNAW) for fellowship support during the writing of this article.

\section{List of References}

Anderson, E.N. 1988. The Food of China. New Haven, Conn.: Yale University Press.

Anderson, Joe L. 2019. Capitalist Pigs: Pigs, Pork, and Power in America. Morgantown: West Virginia University Press. 
Barcellos, Marcia, Klaus Grunert, Yanfeng Zhou, Wim Verbeke, F. Perez-Cueto, and Athanasios Krystallis. 2013. “Consumer Attitudes to Different Pig Production Systems: A Study from Mainland China.” Agriculture and Human Values 30(3): 443-55.

Bar-On, Yinon M., Rob Phillips, and Ron Milo. 2018. “The Biomass Distribution on Earth." Proceedings of the National Academy of Sciences 115(25): 6506-11.

Barton, Loukas, Seth Newsome, Fa-Hu Chen, Hui Wang, Thomas Guilderson, and Robert Bettinger. 2009. "Agricultural Origins and the Isotopic Identity of Domestication in Northern China." Proceedings of the National Academy of Sciences 106 (14): 5523-28.

Baser, Fuller, J. Joe Ford, and Ronald Kensinger. 2001. "Reproductive Physiology." In Biology of the Domestic Pig, eds. Wilson Pond and Harry Mersmann, 150-224. Ithaca, N.Y.: Cornell University Press.

Bewick, Thomas. 1824. A General History of Quadrupeds. 8th ed. Newcastle upon Tyne: Printed by Edward Walker. http:/hdl.handle.net/2027/nc01.ark:/13960/t6f19zq64.

Bielenstein, Hans. 1987. “Chinese Historical Demography A.D. 2-1982.” Bulletin of the Museum of Far Eastern Antiquities 59: 1-288.

Blanchette, Alex. 2015. "Herding Species: Biosecurity, Human Labor, and the American Industrial Pig.” Cultural Anthropology 30(4): 640-69.

Boivin, Nicole L., Melinda A. Zeder, Dorian Q. Fuller, Alison Crowther, Greger Larson, Jon M. Erlandson, Tim Denham, and Michael D. Petraglia. 2016. "Ecological Consequences of Human Niche Construction: Examining LongTerm Anthropogenic Shaping of Global Species Distributions." Proceedings of the National Academy of Sciences 113(23): 6388-96.

Borkenhagen, Laura K., Guo-Lin Wang, Ryan A. Simmons, Zhen-Qiang Bi, Bing Lu, Xian-Jun Wang, Chuang-Xin Wang, et al. 2019. "High Risk of Influenza Virus Infection Among Swine Workers: Examining a Dynamic Cohort in China.” Clinical Infectious Diseases ciz865. https://doi.org/10.1093/cid/ciz865.

Bosse, Mirte, Hendrik-Jan Megens, Laurent A. F. Frantz, Ole Madsen, Greger Larson, Yogesh Paudel, Naomi Dujjvestejjn, et al. 2014. "Genomic Analysis Reveals Selection for Asian Genes in European Pigs Following HumanMediated Introgression." Nature Communications 5: 4392.

Bray, Francesca. 1984. Science and Civilisation in China 6.2: Agriculture. Cambridge: Cambridge University Press.

—. 2018. "Where Did the Animals Go? Presence and Absence of Livestock in Chinese Agricultural Treatises.” In Animals through Chinese History: Earliest Times to 1911, eds. Roel Sterckx, Martina Siebert, and Dagmar Schäfer, 118-38. Cambridge: Cambridge University Press.

Bulliet, Richard W. 2005. Hunters, Herders and Hamburgers: The Past and Future of Human-Animal Relationships. New York: Columbia University Press.

Cheng, Peilieu. 1984. "Livestock Breeds of China." Animal Production and Health Paper 46, Food and Agriculture Organization of the United Nations. http://www. fao.org/3/x6549e/x6549e00.pdf (accessed April 22, 2020).

Clark, Robert Sterling, and Arthur de Carle Sowerby. 1912. Through Shen-Kan: The Account of the Clark Expedition in North China 1908-9. London: T. Fisher Unwin.

Crosby, Alfred W. 1972. The Columbian Exchange: Biological and Cultural Consequences of 1492. Westport, Conn.: Greenwood Press.

Cucchi, Thomas, Ardern Hulme-Beaman, Jing Yuan, and Keith Dobney. 2011. "Early Neolithic Pig Domestication at Jiahu, Henan Province, China: Clues from Molar 
Shape Analyses Using Geometric Morphometric Approaches.” Journal of Archaeological Science 38(1): 11-22.

Cucchi, Thomas, Lingling Dai, Marie Balasse, Chunging Zhao, Jiangtao Gao, Yaowu Hu, and Jing Yuan. 2016. "Social Complexification and Pig (Sus scrofa) Husbandry in Ancient China: A Combined Geometric Morphometric and Isotopic Approach.” PLOS ONE 11(7): e0158523.

Davis, Mike. 2006. The Monster at Our Door: The Global Threat of Avian Flu. New York: Henry Holt.

Davison, Nicola. 2013. "Rivers of Blood: The Dead Pigs Rotting in China's Water Supply.” The Guardian, March 29.

Di Cesare, Mariachiara, James Bentham, Gretchen A. Stevens, Bin Zhou, Goodarz Danaei, Yuan Lu, Honor Bixby, et al. 2016. “Trends in Adult Body-Mass Index in 200 Countries from 1975 to 2014: A Pooled Analysis of 1698 PopulationBased Measurement Studies with 19.2 Million Participants.” The Lancet 387 (10026): 1377-96.

Dooren, Kees van. 2018. "Yangxiang Aims High with Sows on Many Floors." Pig Progress, April 20. https:/www.pigprogress.net/World-of-Pigs1/Articles/2018/4/Yangxiang-aims-high-with-sows-on-many-floors-275164E/ (accessed April 22, 2020).

Emel, Jody, and Harvey Neo, eds. 2015. Political Ecologies of Meat. New York: Routledge.

Ervynck, Anton, Keith Dobney, Hitomi Hongo, and Richard H. Meadow. 2001. “Born Free? New Evidence for the Status of Sus scrofa at Neolithic Çayönü Tepesi (Southeastern Anatolia, Turkey)." Paléorient 27(2): 47-73.

Essig, Mark. 2015. Lesser Beasts: A Snout-to-Tail History of the Humble Pig. New York: Basic Books.

Finlay, Mark R. 2004. "Hogs, Antibiotics, and the Industrial Environments of Postwar Agriculture." In Industrializing Organisms: Introducing Evolutionary History, eds. Susan Schrepfer and Philip Scranton, 237-60. New York: Taylor and Francis.

Fleischman, Thomas. 2017. “'A Plague of Wild Boars': A New History of Pigs and People in Late 20th Century Europe." Antipode 49(4): 1015-34.

Fok, Allison, and Alice Hui. 2017. "China Pork: A Meaty Task to Meet Demand." DBS Asian Insights, Sector Briefing 45, Development Bank of Singapore. https:// www.dbs.com.tw/sme/aics/pdfController.page?pdfpath=/content/article/pdf/AIO/ 072017/170704_insights_a_meaty_task_to_meet_demand.pdf (accessed April 22, 2020).

Food and Agriculture Organization of the United Nations (FAO). 2019. "ASF Situation in Asia Update.” December 12. http://www.fao.org/ag/againfo/programmes/en/ empres/ASF/2019/Situation_update_2019_12_12.html (accessed April 22, 2020).

Foster, John Bellamy, and Fred Magdoff. 2000. "Liebig, Marx, and the Depletion of Soil Fertility: Relevance for Today's Agriculture.” In Hungry for Profit: The Agribusiness Threat to Farmers, Food, and the Environment, eds. Fred Magdoff, John Bellamy Foster, and Frederick H. Buttel, 43-60. New York: Monthly Review Press.

Frantz, Laurent, Erik Meijaard, Jaime Gongora, James Haile, Martien A. M. Groenen, and Greger Larson. 2016. "The Evolution of Suidae.” Annual Review of Animal Biosciences 4: 61-85.

Gaunitz, Charleen, et al. 2018. “Ancient Genomes Revisit the Ancestry of Domestic and Przewalski’s Horses.” Science 360(6384): 111-14.

Gernet, Jacques. 1962. Daily Life in China on the Eve of the Mongol Invasion, 12501276. Stanford, Calif.: Stanford University Press. 
Gibson, Aвraham H. 2016. Feral Animals in the American South: An Evolutionary History. New York: Cambridge University Press.

Grove, Alfred T., and Oliver Rackham. 2001. The Nature of Mediterranean Europe: An Ecological History. New Haven, Conn.: Yale University Press.

Haraway, Donna. 2008. When Species Meet. Minneapolis: University of Minnesota Press.

Hayden, Brian. 1990. "Nimrods, Piscators, Pluckers, and Planters: The Emergence of Food Production." Journal of Anthropological Archaeology 9(1): 31-69.

. 2003. "Were Luxury Foods the First Domesticates? Ethnoarchaeological Perspectives from Southeast Asia." World Archaeology 34(3): 458-69.

Henan sheng bowuguan (Henan Provincial Museum). 1973. "Jiyuan sijiangou san zuo Han mu de fajue” 濟源泗澗溝三座漢墓的發掘 [The excavation of three Han-era tombs at Sijianggou, Jiyuan]. Wenwu 1973(2): 46-56.

Hongo, Hitomi. 2019. "Introduction of Domestic Animals to the Japanese Archipelago." In The Oxford Handbook of Zooarchaeology, eds. Umberto Albarella, Mauro Rizzetto, Hannah Russ, Kim Vickers, and Sarah Viner-Daniels, 333-50. Oxford: Oxford University Press.

— eastern Anatolia)." In Ancestors for the Pigs: Pigs in Prehistory, ed. Sarah Nelson, 77-98. Philadelphia: Museum Applied Science Center for Archaeology.

Hsu, Vera Y. N., and Francis L. K. Hsu. 1977. "Modern China: North.” In Food in Chinese Culture: Anthropological and Historical Perspectives, ed. K. C. Chang, 295-316. New Haven, Conn.: Yale University Press.

Huang, Dekuan 黃德寬, ed. 2007. Guwenzi puxi shuzheng 古文字譜系疏證 [Dictionary of the pedigree of ancient Chinese characters]. Beijing: Shangwu yinshuguan.

Huang, Hsing-Tsung. 2000. Science and Civilisation in China 6.5: Fermentations and Food Science. Cambridge: Cambridge University Press.

Hvistendahl, Mara. 2012. "China Takes Aim at Rampant Antibiotic Resistance.” Science 336(6083): 795.

Ji, Xiuling, Qunhui Shen, Fang Liu, Jing Ma, Gang Xu, Yuanlong Wang, and Minghong Wu. 2012. "Antibiotic Resistance Gene Abundances Associated with Antibiotics and Heavy Metals in Animal Manures and Agricultural Soils Adjacent to Feedlots in Shanghai; China." Journal of Hazardous Materials 235: 178-85.

Jia SiXIE 賈思劦思, MiaO QIYU 繆啟愉, and MiaO GuILONG 繆桂龍. 2006. Qimin yaoshu yizhu 齊民要術譯注 [Essential Techniques for the People with translation and commentary]. Shanghai: Shanghai guji chubanshe.

Jian, Li. 2010. "The Decline of Household Pig Farming in Rural Southwest China: Socioeconomic Obstacles and Policy Implications." Culture \& Agriculture 32(2): 61-77.

Kim, Seung-Og. 1994. "Burials, Pigs, and Political Prestige in Neolithic China." Current Anthropology 35(2): 119-141.

Kirch, Patrick Vinton. 2017. On the Road of the Winds: An Archaeological History of the Pacific Islands before European Contact. Oakland: University of California Press.

Kuo, Chunghao Pio. 2013. "Pigs, Pork and Ham: The Practice of Pig Farming and the Consumption of Pork in Ming-Qing China." PhD diss., New York University.

Lander, Brian, and Katherine Brunson. 2018. "Wild Mammals of Ancient North China." Journal of Chinese History 2(2): 291-312.

Larson, Greger, Umberto Albarella, Keith Dobney, Peter Rowley-Conwy, Jörg Schibler, Anne Tresset, Jean-Denis Vigne, et al. 2007. "Ancient DNA, Pig Domestication, and the Spread of the Neolithic into Europe." Proceedings of the National Academy of Sciences 104(39): 15276-81. 
Larson, Greger, Keith Dobney, Umberto Albarella, Meiying Fang, Elizabeth Matisoo-Smith, Judith Robins, Stewart Lowden, et al. 2005. "Worldwide Phylogeography of Wild Boar Reveals Multiple Centers of Pig Domestication." Science 307(5715): 1618-21.

Larson, Greger, and Dorian Fuller. 2014. "The Evolution of Animal Domestication." Annual Review of Ecology, Evolution, and Systematics 45: 115-36.

Larson, Greger, Ranran Liu, Xingbo Zhao, Jing Yuan, Dorian Fuller, Loukas Barton, Keith Dobney, et al. 2010. "Patterns of East Asian Pig Domestication, Migration, and Turnover Revealed by Modern and Ancient DNA." Proceedings of the National Academy of Sciences 107(17): 7686-91.

Liu, Li. 1996. "Mortuary Ritual and Social Hierarchy in the Longshan Culture." Early China 21: 1-46.

— and Xingcan Chen. 2012. The Archaeology of China: From the Late Paleolithic to the Early Bronze Age. Cambridge: Cambridge University Press.

Lord, Elizabeth. 2020. "China's Eco-Dream and the Making of Invisibilities in RuralEnvironmental Research.” In Can Science and Technology Save China?, eds. Susan Greenhalgh and Li Zhang, 115-38. Ithaca, N.Y.: Cornell University Press.

Luo, Yi, Daqing Mao, Michal Rysz, Qixing Zhou, Hongjie Zhang, Lin Xu, and Pedro J. J. Alvarez. 2010. "Trends in Antibiotic Resistance Genes Occurrence in the Haihe River, China.” Environmental Science \& Technology 44(19): 7220-25.

LuO, YunBING 羅運兵. 2012. Zhongguo gudai zhu lei xunhua, siyang yu yishixing shiyong 中國古代豬類馴化飼養與儀式性使用 [The domestication, feeding and ritual uses of pigs in ancient China]. Beijing: Kexue chubanshe.

LuO Yunbing 羅運兵 and Zhang JuzHong 張居中. 2008. “Henan Wuyang xian Jiahu yizhi chutu zhu gu de zai yanjiu” 河南舞陽縣賈湖遺址出土猪骨的再研究 [Further study of the pig bones excavated at the Jiahu site in Wuyang County, Henan]. Kaogu 2008(1): 90-96.

Ma, XIAOLIn. 2005. Emergent Social Complexity in the Yangshao Culture: Analyses of Settlement Patterns and Faunal Remains from Lingbao, Western Henan, China (c. 4900-3000 BC). Oxford: Archaeopress.

馬蕭林. 2007. “Linbao Xipo yizhi jiazhu de nianling jiegou ji xiangguan wenti” 靈寶 西坡遺址家豬的年齡結構及相關問題 [Age structure and related topics on the domestic pigs from the Xipo site in Lingbao]. Huaxia kaogu 2007(1): 55-74.

Ma, Xiu Q., Julia M. Verkuil, Helene C. Reinbach, and Lene Meinert. 2017. "Which Product Characteristics Are Preferred by Chinese Consumers When Choosing Pork? A Conjoint Analysis on Perceived Quality of Selected Pork Attributes." Food Science \& Nutrition 5(3): 770-75.

Ma, Ying, Benjamin T. Fuller, Dong Wei, Lei Shi, Xiaozheng Zhang, Yaowu Hu, and Michael P. Richards. 2016. "Isotopic Perspectives $\left(\delta^{13} \mathrm{C}, \delta{ }^{15} \mathrm{~N}, \delta^{34} \mathrm{~S}\right)$ of Diet, Social Complexity, and Animal Husbandry during the Proto-shang Period (ca. 2000-1600 BC) of China." American Journal of Physical Anthropology 160(3): $433-45$.

MacKinnon, Michael. 2001. "High on the Hog: Linking Zooarchaeological, Literary, and Artistic Data for Pig Breeds in Roman Italy." American Journal of Archaeology 105(4): 649-73.

Malcolmson, Robert W., and Stephanos Mastoris. 1998. The English Pig: A History. London: Hambledon Press.

Marks, Robert B. 2017. China: An Environmental History. 2nd ed. Lanham, Md.: Rowman \& Littlefield. 
Marshall, Fiona B., Keith Dobney, Tim Denham, and José M. Capriles. 2014. "Evaluating the Roles of Directed Breeding and Gene Flow in Animal Domestication." Proceedings of the National Academy of Sciences 111(17): 6153-58.

McOrist, Steven. 2009. "Native Pig Breeds of China." Pig Progress, May 1. https://www. pigprogress.net/Breeding/Genetics-Al/2009/5/Native-pig-breeds-of-China-PP005933W/ (accessed April 22, 2020).

Megens, Hendrik-Jan, Richard P. M. A. Crooijmans, Magali San Cristobal, Xiao Hui, Ning Li, and Martien A. M. Groenen. 2008. "Biodiversity of Pig Breeds from China and Europe Estimated from Pooled DNA Samples: Differences in Microsatellite Variation between Two Areas of Domestication." Genetics Selection Evolution 40(1): 103-28.

Mikhail, Alan. 2014. The Animal in Ottoman Egypt. Oxford: Oxford University Press.

Mizelle, Brett. 2011. Pig. London: Reaktion Books.

Morand, Serge K., Marie McIntyre, and Matthew Baylis. 2014. "Domesticated Animals and Human Infectious Diseases of Zoonotic Origins: Domestication Time Matters." Infection, Genetics and Evolution 24: 76-81.

Morton, Timothy. 2017. Humankind: Solidarity with Nonhuman People. London: Verso.

Nemeth, David J. 1998. "Privy-Pigs in Prehistory? A Korean Analog for Neolithic Chinese Subsistence Practices." In Ancestors for the Pigs: Pigs in Prehistory, ed. Sarah Nelson, 11-25. Philadelphia: Museum Applied Science Center for Archaeology.

Nowak, Ronald. 1999. Walker's Mammals of the World. Baltimore: Johns Hopkins University Press.

Oklahoma State University (OSU). 2019. "Meishan Swine." http://afs.okstate.edu/ breeds/swine/meishan/ (accessed April 22, 2020).

Oliveira, Gustavo de L. T., and Susanna B. Hecht. 2018. Soy, Globalization, and Environmental Politics in South America. New York: Routledge.

Oliveira, Gustavo de L. T., and Mindi Schneider. 2015. "The Politics of Flexing Soybeans: China, Brazil and Global Agroindustrial Restructuring." Journal of Peasant Studies 43(1): 1-28.

Ottoni, Claudio, Linus Girdland Flink, Allowen Evin, Christina Geörg, Bea De Cupere, Wim Van Neer, László Bartosiewicz, et al. 2013. "Pig Domestication and Human-Mediated Dispersal in Western Eurasia Revealed through Ancient DNA and Geometric Morphometrics." Molecular Biology and Evolution 30(4): 824-32.

Parsons, James J. 1962. “The Acorn-Hog Economy of the Oak Woodlands of Southwestern Spain.” Geographical Review 52(2): 211-35.

Pastoureau, Michel. 2009. Le cochon: Histoire d'un cousin mal aimé [The pig: A history of an unloved cousin]. Paris: Gallimard.

Pearce-Duvet, Jessica M. C. 2006. "The Origin of Human Pathogens: Evaluating the Role of Agriculture and Domestic Animals in the Evolution of Human Disease." Biological Reviews 81(3): 369-82.

Pechenkina, Ekaterina A., Stanley H. Ambrose, Ma Xiaolin, and Robert A. Benfer Jr. 2005. "Reconstructing Northern Chinese Neolithic Subsistence Practices by Isotopic Analysis." Journal of Archaeological Science 32(8): 1176-89.

Price, Max, and Hitomi Hongo. Forthcoming. "The Archaeology of Pig Domestication in Eurasia." Journal of Archaeological Research. Published ahead of print, December 19, 2020. https://doi.org/10.1007/s10814-019-09142-9. 
Pugliese, Carolina, Giuseppe Madonia, Vincenzo Chiofalo, Saverio Margiotta, Anna Acciaioli, and Gustavo Gandini. 2003. "Comparison of the Performances of Nero Siciliano Pigs Reared Indoors and Outdoors. 1. Growth and Carcass Composition." Meat Science 65(2): 825-31.

QI, GUOQIn 祁國琴, Lin Zhongyu 林種雨, and An JiAyuAn 安家瑗. 2006. “Dadiwan yizhi dongwu yicun jianding baogao 大地灣遺址動物遺存鑒定報告” [A report on the animal remains excavated from the Dadiwan site]. In Qin'an Dadiwan: xinshiqi shidai yizhi fajue baogao 秦安大地灣: 新石器時代遺址發掘報告 [Qin’an Dadiwan: An excavation report from a Neolithic site], ed. Gansu sheng wenwu kaogu yanjiusuo, 861-910. Beijing: Wenwu chubanshe.

Rappaport, Roy. 1967. Pigs for the Ancestors: Ritual in the Ecology of a New Guinea People. New Haven, Conn.: Yale University Press.

Redding, Richard, and Michael Rosenberg. 1998. "Ancestral Pigs: A New (Guinea) Model for Pig Domestication in the Middle East." In Ancestors for the Pigs: Pigs in Prehistory, ed. Sarah Nelson, 65-76. Philadelphia: Museum Applied Science Center for Archaeology.

Ritvo, Harriet. 1987. The Animal Estate: The English and Other Creatures in the Victorian Age. Cambridge, Mass.: Harvard University Press.

Schmalzer, Sigrid. 2002. "Breeding a Better China: Pigs, Practices, and Place in a Chinese County." Geographical Review 92(1): 1-22.

. 2016. Red Revolution, Green Revolution: Scientific Farming in Socialist China. Chicago: University of Chicago Press.

Schneider, Mindi. 2014. "Developing the Meat Grab.” Journal of Peasant Studies 41(4): 613-33.

. 2017. "Dragonhead Enterprises and the State of Agribusiness in China." Journal of Agrarian Change 17(1): 3-21.

2019. "China’s Global Meat Industry: The World-Shaking Power of Pigs and Pork in China’s Reform Era.” In Global Meat: Social and Environmental Consequences of the Expanding Meat Industry, eds. Bill Winders and Elizabeth Ransom, 79-100. Cambridge, Mass.: MIT Press.

, and Shefali Sharma. 2014. China's Pork Miracle? Agribusiness and Development in China's Pork Industry. Minneapolis: Institute for Agriculture and Trade Policy.

Schwartz, Adam C. 2019. "Shang Sacrificial Animals: Material Documents and Images." In Animals through Chinese History: Earliest Times to 1911, ed. Roel Sterckx, Martina Siebert, and Dagmar Schäfer, 20-45. Cambridge: Cambridge University Press.

2020. The Oracle Bones from Huayuanzhuang East. Berlin: De Gruyter.

Shi, Yan, Cunwang Cheng, Peng Lei, Tiejun Wen, and Caroline Merrifield. 2011. "Safe Food, Green Food, Good Food: Chinese Community Supported Agriculture and the Rising Middle Class." International Journal of Agricultural Sustainability 9 (4): 551-58.

Shin, Sheng-han. 1982. A Preliminary Study of the Book Ch'i Min Yao Shu: An Agricultural Encyclopaedia of the 6th Century. 2nd ed. Beijing: Science Press.

Skabelund, Aaron H. 2011. Empire of Dogs: Canines, Japan, and the Making of the Modern Imperial World. Ithaca, N.Y.: Cornell University Press.

Smil, Vaclav. 2008. Energy in Nature and Society: General Energetics of Complex Systems. Cambridge, Mass.: MIT Press.

2013. Harvesting the Biosphere: What We Have Taken from Nature. Cambridge, Mass.: MIT Press. 
Smith, Andrew T., and Yan Xie, eds. 2008. A Guide to the Mammals of China. Princeton, N.J.: Princeton University Press.

Song, Yang, Xuemei Li, and Lishi Zhang. 2014. "Food Safety Issues in China." Iranian Journal of Public Health 43(9): 1299-1300.

Speake, Jennifer. 2015. Oxford Dictionary of Proverbs. Oxford: Oxford University Press. Springmann, Marco, Michael Clark, Daniel Mason-D’Croz, Keith Wiebe, Benjamin Leon Bodirsky, Luis Lassaletta, Wim de Vries, et al. 2018. "Options for Keeping the Food System within Environmental Limits." Nature 562(7728): 519-25.

Swindle, M. Michael, and Alison C. Smith, eds. 2015. Swine in the Laboratory: Surgery, Anesthesia, Imaging, and Experimental Techniques. Boca Raton, Fla.: CRC Press.

Tang, Zhonglin, Zhongzhen Peng, Bang Liu, Bin Fan, Shuhong Zhao, Xiaoping Li, Sanping Xu, and Kui Li. 2008. "Effect of Breed, Sex and Birth Parity on Growth, Carcass and Meat Quality in Pigs." Frontiers of Agriculture in China 2(3): 331-37.

Trautmann, Thomas R. 2015. Elephants and Kings: An Environmental History. Chicago: University of Chicago Press.

US Department of Agriculture, Foreign Agricultural Service (USDA). 2018. "Livestock and Poultry: World Markets and Trade.” April 9. https://www.fas.usda.gov/data/ livestock-and-poultry-world-markets-and-trade (accessed April 22, 2020).

US Department of Agriculture, Foreign Agricultural Service (USDA). 2020. "China: Livestock and Products Semi-Annual Report.” April 16. https://www.fas.usda.gov/ data/china-livestock-and-products-semi-annual-5 (accessed April 23, 2020).

Vigne, Jean-Denis, Isabelle Carrère, François Briois, and Jean Guilaine. 2011. "The Early Process of Mammal Domestication in the Near East. New Evidence from the Pre-Neolithic and Pre-Pottery Neolithic in Cyprus." Current Anthropology 52(S4): S255-71.

Wallace, Robert G. 2016. Big Farms Make Big Flu: Dispatches on Infectious Disease, Agribusiness, and the Nature of Science. New York: Monthly Review Press.

Wang, Jimin, and Mariko Watanabe. 2008. "Pork Production in China: A Survey and Analysis of the Industry at a Lewis Turning Point.” ASEDP 77, Institute of Developing Economies, Japan External Trade Organization. https://www.ide.go.jp/ English/Publish/Download/Asedp/077.html.

WANG YUHU 王毓瑚. 2006. Zhongguo nongxue shulu 中國農學書錄 [A bibliography of Chinese agronomy]. Beijing: Zhonghua shuju.

WANG YUXIN 王宇信 and YANG SHENGNAN 楊升南, eds. 1999. Jiaguxue yibai nian 甲骨學 一百年 [A hundred years of oracle bone studies]. Beijing: Shehui kexue wenxian chubanshe.

Watson, Lyall. 2004. The Whole Hog: Exploring the Extraordinary Potential of Pigs. Washington, D.C.: Smithsonian Books.

White, SAm. 2011. "From Globalized Pig Breeds to Capitalist Pigs: A Study in Animal Cultures and Evolutionary History.” Environmental History 16(1): 94-120.

Wittwer, Sylvan, Youtai Yu, Sun Han, and Lianzheng Wang. 1987. Feeding a Billion: Frontiers of Chinese Agriculture. East Lansing: Michigan State University Press.

Woolsey, Michael, and Jianping Zhang. 2010. "China, People’s Republic of: Livestock and Products Semi-Annual Report 2010.” GAIN Report CH10009, US Department of Agriculture, Foreign Agricultural Service.

Worster, Donald. 2017. "The Good Muck: Toward an Excremental History of China." RCC Perspectives 5: 1-54. 
Wu, Xiaohong, Chi Zhang, Paul Goldberg, David Cohen, Yan Pan, Trina Arpin, and Ofer Bar-Yosef. 2012. "Early Pottery at 20,000 Years Ago in Xianrendong Cave, China." Science 336(6089): 1696-1700.

Xiang, Hai, Jianqiang Gao, Dawei Cai, Yunbing Luo, Baoquan Yu, Langqing Liu, Ranran Liu, et al. 2017. "Origin and Dispersal of Early Domestic Pigs in Northern China.” Scientific Reports 7: 5602.

XIAO FAN 蕭璠. 1986. “Guanyu Liang Han Wei jin shiqu yangzhu yu jifei wenti de ruogan jiantao” 關於兩漢魏晉時期養猪與積肥間題的若干檢討 [An examination of some issues regarding pig husbandry and manure in the Han-Wei-Jin period]. Zhongyang yanjiuyuan lishi yuyan yanjiusuo jikan 中央研究院歷史語言研究所集刊 [Bulletin of the Institute of History and Philology Academia Sinica] 57: 617-34.

Xiao Hong-b, Qiong Chen, Ji-min Wang, Les Oxley, and Heng-yun Ma. 2015. "The Puzzle of the Missing Meat: Food Away from Home and China's Meat Statistics." Journal of Integrative Agriculture 14(6): 1033-44.

Yan, Hairong, Chen Yiyuan, and Ku Hok Bun. 2016. "China’s Soybean Crisis: The Logic of Modernization and Its Discontents.” Journal of Peasant Studies 43(2): 373-95.

YANG, Hongjie. 2013. "Livestock Development in China: Animal Production, Consumption and Genetic Resources." Journal of Animal Breeding and Genetics 130(4): 249-51.

— 2015. "China's Second National Animal Genetic Resources Survey." In The State of the World's Animal Genetic Resources for Food and Agriculture, 247. Rome: Food and Agriculture Organization of the United Nations. http://www.fao.org/3/a-i4787e. pdf.

YANG SHEN 楊屾. [1740] 1962. Bin feng guang yi 圈風廣義 [A comprehensive record of the customs in Bin]. Beijing: Nongye chubanshe.

YANG WENXIU 楊文繡. 1959. Zhu duo fei duo liangchan gao 猪多肥多粮產高 [More pigs means more fertilizer and higher grain production]. Shanghai: Shanghai renmin meishu chubanshe. https://chineseposters.net/posters/pc-1959-013.php.

Yang, Xiaoyan, Zhinei Wan, Linda Perry, Houyuan Lu, Qiang Wang, Chaohong Zhao, Jun Li, et al. 2012. "Early Millet Use in Northern China." Proceedings of the National Academy of Sciences 109(10): 3726-30.

Yuan, Jing, and Rowan K. Flad. 2002. "Pig Domestication in Ancient China.” Antiquity 76(293): 724-32.

Yuan, Jing, and Rowan K. Flad. 2005. "New Zooarchaeological Evidence for Changes in Shang Dynasty Animal Sacrifice." Journal of Anthropological Archaeology 24(3): 252-70.

YUAN, JING 袁靖. 1999. “Lun Zhongguo xinshiqi shidai jumin huoqu roushi ziyuan de fangshi” 論中國新石器時代居民獲取肉食資源的方式 [On the ways people in Neolithic settlements in China obtained meat resources]. Kaogu xuebao 1999(1): $1-22$.

——袁靖. 2006. “Zhongguo gudai de jiazhu qiyuan” 中國古代的家豬起源 [The origins of domestic pigs in ancient China]. In Xibu kaogu 西部考古 [Archaeology of the West], ed. Xibei daxue, 44-47. Xi'an: Sanqin chubanshe.

袁靖, and YANG MenGFEI 楊夢菲. 2004. “Dongwu yanjiu”動物研究 [Zooarchaeology]. In Kuahuqiao 跨湖橋, eds. Zhejiang sheng wenwu kaogu yanjiusuo and Xiaoshan bowuguan, 241-69. Beijing: Wenwu chubanshe.

Zeder, Melinda A. 2012a. "The Domestication of Animals." Journal of Anthropological Research 68(2): 161-90. 
Zeder, Melinda A. 2012b. "Pathways to Animal Domestication." In Biodiversity in Agriculture: Domestication, Evolution, and Sustainability, ed. Paul Gepts et al., 227-59. Cambridge: Cambridge University Press.

Zhang LÜXIANG 張履祥 (1611-74) and Chen Hengli 陳恆力 (1911-78), eds. 1983. Bunongshu jiaoshi 補農書校釋 [A supplement to the Agricultural Handbook, collated and annotated]. Beijing: Nongye chubanshe.

Zhang, ZongFa 張宗法. 1989. Sannongji jiaoshi 三農紀校釋 [Records of the Three Kinds of Agriculture, collated and annotated]. Beijing: Nongye chubanshe.

Zhongguo shehui kexueyuan kaogu yanjiusuo. 1997. "Neimenggu Aohanqi Xinglongwa juluo yizhi 1992 nian fajue jianbao” 内蒙古敖漢旗興隆洼聚落遺址1992年發掘簡 報 [A brief report on the 1992 excavation of the Xinglongwa site at Aohanqi, Inner Mongolia]. Kaogu 1997(1): 1-26. 